University for Business and Technology in Kosovo

UBT Knowledge Center

UBT International Conference

2016 UBT International Conference

Oct 28th, 9:00 AM - Oct 30th, 5:00 PM

\title{
An Evaluation on Applications of Sustainable Approaches in Condominiums
}

Nida Yildirim

University for Business and Technology, nida.yildirim@ubt-uni.net

Follow this and additional works at: https://knowledgecenter.ubt-uni.net/conference

Part of the Architecture Commons

\section{Recommended Citation}

Yildirim, Nida, "An Evaluation on Applications of Sustainable Approaches in Condominiums" (2016). UBT International Conference. 71.

https://knowledgecenter.ubt-uni.net/conference/2016/all-events/71

This Event is brought to you for free and open access by the Publication and Journals at UBT Knowledge Center. It has been accepted for inclusion in UBT International Conference by an authorized administrator of UBT Knowledge Center. For more information, please contact knowledge.center@ubt-uni.net. 


\title{
An Evaluation on Applications of Sustainable Approaches in Condominiums
}

\author{
Nida Yıldırım \\ UBT - Higher Education Institution, Lagjja Kalabria, 10000 p.n., \\ Prishtine, Kosovo \\ nida.yildirim@ubt-uni.net
}

\begin{abstract}
Nowadays, as the result of the damage caused by building sector to the environment and with increased depletion of natural resources, sustainable architecture has required to be an integral part of the construction industry. To prevent unhealthy construction and to increase the number of sustainable or green buildings in terms of the environment, there were established several sustainable building rating systems. These sustainable building rating systems, while maintaining human health and comfort, also try to decrease the damage of the environment to a lower level. However, rating systems have specific criteria depending on their countries climate and culture. Therefore, these systems cannot be applied in less developed countries or in different climate areas because the criteria of these systems sometimes do not represent the local situation. This study aims to develop general criteria for sustainable condominiums that can be used in all countries, regardless to their economic or regional differences.
\end{abstract}

Keywords: Sustainable architecture, Condominiums, Sustainable building, Criteria

\section{Introduction}

Within itself of nature, there is a balance and integrity. Therefore, we need to sustain our lives in harmony with natural environment. Since ancient times living species in order to meet accommodation needs, they were localized in shelters and caves. Throughout the history, people's primary needs have been developed and change which have reached in today's modern buildings. However, over the years with development of the needs and requirements for a comfortable lifestyle, the damage of nature was increased continuously. As the result, people have started to use nature as more as possible in order to respond to their needs and requirements. With the rapidly rising of the world population, industrialization, unhealthy urbanization, rapid technological developments and along with it increased demand for energy has caused the emergence of problems such as the natural energy resources depletion, global warming and environmental pollution. In this regard, to reduce the damages of environment and to raise the awareness in building industry there were held a number of conferences and meetings in which it was presented many sustainable solutions for a sustainable live. Sustainability could be defined as an ability or capacity of something to be maintained or to sustain itself.

In this study through a literature review were discussed the concept of sustainability and sustainable architecture. In addition, it was aimed to develop general criteria for sustainable condominiums. These criteria were created by main categories of BREEAM and LEED rating systems. In this context a certified building in Izmir, Turkey was examine with these five common categories. 


\section{Sustainability and Sustainable Development}

As the result of the rapidly rising of the world population, industrialization, unhealthy urbanization, rapid technological developments and along with it increased demand for energy has caused the emergence of problems such as the natural energy resources depletion, global warming and environmental pollution. All these environmental problems have brought the concept of sustainability to human life.

The building and construction sector has a huge impact both on human life and on environment through material, energy consumption, the consequent pollution and waste. The built environment also has a crucial impact on the physical and economic health and wellbeing of mankind. Faced with these dangers, each passing day we are becoming more conscious of the need to protect our natural environment. One response to these issues is to approach architecture and urbanism in a way which respects the environment, especially environmental friendly architecture.

Despite being one of the most topical issues in nowadays, in architectural terms sustainability is very little thought given to making the new housing stock environmentally friendly. Achieving sustainability requires us to live within the limits of the earth's capacity in order to provide the materials for building sector and to absorb the waste and pollution that our activities generate (Halliday, 2008).

Sustainability in a general world view is the way of life to provide peoples economic, environmental and social needs without compromising the ability of future generations to meet their own needs. According to Guy Dauncey sustainability means living, working and behaving in a way that will sustain the integrity and biodiversity of the local, regional and planetary ecosystem upon which all life depends. In other words sustainability means achieving the quality of the life that we are looking for without compromising the integrity of planet's ecosystem (Dauncey, n.d).

The concept of sustainable development firstly was use in 1980's in terms of the sustainability of humanity on the planet. However, on 20 March 1987 the World Commission on Environment and Development, also known as the Brundtland Report, sustainability was defined as a part of sustainable development. According to Brundtland report sustainable development is: "development which meets the needs of the present without compromising the ability of future generations to meet their own needs." (Drexhage \& Murphy, 2010). The report highlighted three fundamental components to sustainable development: environmental, social and economic sustainability (Figure 1.1);

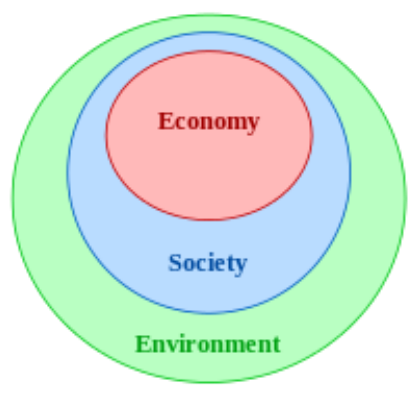

Fig. 5. Three pillars of sustainability (Three pillars of sustainability, n.d) 
Book of Proceedings

International Conference on Architecture and Spatial Planning

A sustainable approach is a systems-based approach that seeks to understand the interactions, which exist among these three pillars (environment, social, and economic sustainability) (Sustainability Primer, n.d.).

Although the objectives of sustainable development were discussed in 1970s, in the Brundtland Report for the first time have been identified two main objectives, the concept of "needs", in particular the essential needs of the world's poor; and the idea of limitations imposed by the state of technology and social organization on the environment's ability to meet present and future needs.

Based on all this information, one of the most important objectives of the concept of sustainability is to create and maintain the conditions under which humans and nature can exist in productive harmony, that permit fulfilling the social, economic and other requirements of present and future generations (Sustainability, n.d.).

\section{Sustainable Architecture}

Today, as a result of the damage caused by building sector to the environment and increased depletion of natural resources, sustainable architecture has required to be an integral part of the construction industry. Considering that buildings consume over $40 \%$ of the raw materials and energy produced in the world, a significant reduction of pollution and greenhouse gas emissions could be achieved in the building industry.

Sustainable architecture is architecture, which is designed in an environmentally friendly way. In other words sustainability in architecture, as understood by modern society today, is an inadequate measure for current and future architectural design, for it aims no higher than trying to make buildings "less bad" (Littman, 2009). The goal of sustainable or "green" architecture is to create structures which are beautiful and functional, but which also contribute to a sustainable lifestyle and culture. Truly sustainable architecture could be defined as the creation of buildings for which only renewable resources are consumed throughout the process of design, construction and operation (Sustainable architecture, n.d.).

\subsection{Sustainable Building and Sustainable Building Rating Systems}

Energy efficient and environmental friendly sustainable buildings are seen as the solution of all growing environmental problems. To increase the number of these sustainable or green buildings in terms of the environment, there have been created several sustainable building rating systems (Table 3.1) i.e. PAPOOSE and TEAM (France), BEAT 2002 (Denmark), Bees (America), EcoQuantum (Netherlends) BREEAM (England), LEED (USA), Green Star (Australia), CASBEE (Japan) and SBTool. 
An Evaluation on Applications of Sustainable Approaches in Condominiums

Table 1. Assessment and certification systems in the world (Yeşil bina ölçüm sistemleri, n.d)

\begin{tabular}{ll}
\hline Countries & Assessment Systems \\
\hline USA & LEED \\
England & BREEAM \\
Japan & CASBEE \\
South Korea & Green Building System \\
Brazil & Aqua / LEED Brazil \\
Canada & LEED Canada / Green Globes \\
China & GB \\
Finland & Promise \\
France & HQE \\
Germany & DGNB \\
Hong Kong & HHBEAM \\
India & GRIHA / LEED India \\
Israel & SI-5281 \\
Italy & ITHACA Protocol \\
Mexico & LEED \\
New Zealand & Green Star New Zealand \\
Netherlands & BREEAM Netherlands \\
Portugal & Leader A \\
Singapore & CONQUAS \\
South Africa & Green Star SA \\
Spain & VERDE \\
Sweden & Environmental Status \\
Norway & EcoProfile \\
International & SBTool \\
Australia & Green Star \\
\hline
\end{tabular}

Today the World Green Council (WGBC) has determined four systems that have been accepted by most countries. These are; BREEAM, LEED, Green Star, CASBEE and SBTool. These sustainable building rating systems while maintaining human health and comfort, also try to decrease the damage of the environmental to a lower level.

\subsection{BREEAM (Building Research Establishment Environmental Assessment Methodology)}

BREEAM, first published by the Building Research Establishment (BRE) in 1990 is the world's longest established and most widely used method of assessing, rating, and certifying the sustainable buildings. Today, more than 250,000 buildings have been BREEAM certified and over a million are registered for certification many in the UK and others in more than 50 countries around the world (Best of BREEAM, n.d).

BREEAM sets the standard for best practice in sustainable building design, construction and operation and has become one of the most comprehensive and widely recognized measures of a building's environmental performance. It encourages designers, clients and others to think about low carbon and low impact design, minimizing the energy demands created by a building. BREEAM awards points and groups the environmental impacts as follows:

- Energy: operational energy and carbon dioxide (CO2)

- Management: management policy, commissioning, site management and procurement 
Book of Proceedings

International Conference on Architecture and Spatial Planning

- Health and Wellbeing: indoor and external issues (noise, light, air, quality etc.)

- Transport: transport-related CO2and location related factors

- Water consumption and efficiency

- Materials: embodied impacts of building materials, including lifecycle impacts like embodied carbon dioxide Waste: construction resource efficiency and operational waste management and minimization

- Pollution: external air and water pollution

- Land Use: type of site and building footprint

- Ecology: ecological value, conservation and enhancement of the site (Breeam, n.d.)

The total number of points or credits gained in each section is multiplied by an environmental weighting factor, which takes into account the relative importance of each section. Section scores are then added together to produce a single overall score. Once the overall score for the building is known this is translated into a rating on a scale of (Breeam, n.d.):

Table 2. BREEAM ratings 2014 (BREEAM, n.d)

\begin{tabular}{ll}
\hline BREEAM Certification Degree & Score \\
\hline Pass & $\geq 30$ \\
Good & $\geq 45$ \\
Very Good & $\geq 55$ \\
Excellent & $\geq 70$ \\
Outstanding & $\geq 80$ \\
\hline
\end{tabular}

\subsection{LEED (Leadership in Energy and Environmental Design)}

Leadership in Energy and Environmental Design or LEED is a national certification system developed by the U.S. Green Building Council ( USGBC). LEED was established as a way to define and measure "green buildings." LEED is a voluntary rating system that has a particular rating system for each building; LEED New Construction, LEED Existing Buildings, LEED for Commercial Interiors and LEED for Core and Shell and LEED H, a rating system for Homes.

LEED Houses certification process breaks the into eight components and offers points in each category to measure overall performance..

LEED certification system starts rating from Certified, Silver, Gold and Platinum based on the number of points.

Table 3. LEED ratings 2014 (Leadership in energy \& environmental design, n.d)

\begin{tabular}{ll}
\hline LEED Certification Degree & Score \\
\hline Certified & $40-49$ \\
Silver & $50-59$ \\
Gold & $60-79$ \\
Platinium & $80+$ \\
\hline
\end{tabular}

Points are offered in seven categories for adopting specified building practices, materials or products. 
- Innovation and Design Location and Linkages

- Sustainable Sites

- Water Efficiency

- $\quad$ Energy and Atmosphere

- Materials and Resources

- Indoor Air Quality

- $\quad$ Awareness and Education (Leed platinum certification, n.d.)

\subsection{Common Criteria for Sustainable Building Rating System}

To raise the awareness and to reduce the negative impact of building sector on the environment and on human health, there have been created several sustainable building rating systems. These voluntary established rating systems are being applied in many different countries from America to Eastern Europe and Japan. Each country has a specific criteria and rating system depending on the climate and culture. However, these systems cannot be applied in less developed countries or in different climate areas because the criteria of certification systems sometimes do not represent the local situation.

In this part of the study were compared main categories of the most widely used BREEAM and LEED certification systems. Than, in order to achieve common criteria that can be used all over the world, the two certifications systems categories were grouped in five common criteria. And they are;

- Sun

- Water

- Air Quality

- Material

- Transportation

Through these five common criteria it was aimed to develop a general criteria for sustainable condominiums that can be used in all countries, regardless to their economic or regional differences. In contrast to the certification system, these criteria have no need to pre-requisite criteria and are expected to be applicable in any region of the world.

\section{An Evaluation of Sustainable Buildings in the World and Turkey Through Common Criteria}

\subsection{Certified Sustainable Buildings In The World}

\section{Building: Mosler Lofts}

Location: Seattle, Washington, USA

Architect: Mithun

Year: 2008

Project Area: 22,557 m2

Received Certification: LEED

Certification Level: Silver

Assessment Plan: New Building Rating System LEED v3 (NC) 
Location: Situated at the north end of Belltown across from the historically vibrant Seattle center, the 150-residential loft tower offers environmental quality as an urban lifestyle choice for downtown Seattlees growing live and work community.

Architectural Concept: Designed by Mithun, the 12-story Mosler Lofts were the first LEED Silver certified condos in Seattle (Figure 5.1). An example of how to create value through innovative, sustainable design beyond an initial development vision, this development was $90 \%$ sold within the first 6 months on the market due to its highly sustainable features and contemporary design(Mosler Lofts green story, 2008)

\section{Sustainable Design Features}

1. Sun: The building's extensive glazing helps maximize passive heating during the winter. Operable windows, patio doors, shading from balconies, and interior sunshades temper heat gain during the summer. Every residential unit also has individual control of its heating and cooling, allowing the south side to be cooling while the north side may require heating (Dahl\& Gurry, n.d.).

2. Water: The project has introduced many storm water management improvements to the site. Forty-three percent of exterior street level area has been converted into landscape and 18 percent of the roof area into gardens (Dahl\& Gurry, n.d.).

3. Air Quality: Operable windows, glass patio doors and massive sliding glass walls offer opportunities for natural ventilation, cooling, warming. Fifty-five percent of the building can be ventilated or cooled with operable windows (Mosler Lofts green story, 2008).

4. Materials: Although the density of units is high, the proportionate material use is low. Wall area was minimized through innovative open plans to provide simple, flexible living spaces. More than 40 percent of materials used on the project were extracted and manufactured within $500 \mathrm{~km}$ of the site (Dahl\& Gurry, n.d.).

5. Transportation: The project capitalizes on its central location from which residents can walk, bike, bus or drive. Bicycle storage and a changing area are provided in the garage. Each resident is given a free membership to use the hybrid Flexcar available on site. Parking is underground to maximize the use of the site, but to decrease dependency on vehicles, the site does not mandate parking (Dahl\& Gurry, n.d.).

\section{Vega Building - Hove, England}

Building: Vega

Location: Hove, East Sussex, England

Architect: Pollard Thomas Edwards Architects

Year: 2013

Received Certification: BREEAM

Assessment Plan: CSH (Code for Sustainable Homes) level 4

Location: The new social housing apartment block at 331 Kingsway, Hove was given the name The Vega Building to fit with the art deco styling of the proposal. The site was formerly a garage built in the 1930's that was modelled in the Art Deco style - sadly demolished in 2001. The name Vega relates to the Lockheed Vega, the plane famously flown by Amelia Earhart across the Atlantic single-handed (Press cuttings for Vega building identity and signage design, 2013).

Architectural Concept: In Vega building38 apartment were designed as social housing. Architect of the building developed a brief that suggested an identity that was influenced by the clean lines of the art deco style, in a contemporary way (Figure 5.3). Sustainable Design Features

1. Sun: Vega building achieved CSH Level 4, with high levels of natural light and a highly efficient centralized heating system. Photovoltaic panels provide power to communal areas, including lighting for the columns at the front of the building. 
2. Water: Inside all the apartments in the Vega building, were used water conserving fixtures such as low-flow toilets, low-flow showers, Energy Star dishwashers and washing machines to allow residents to minimize their water use.

3. Air Quality: Operable windows offer opportunities for natural ventilation, cooling and warming. A large percentage of the apartments is ventilated or cooled through these operable windows.

4. Materials: In Vega building a large percentage of the materials are recycling.

5. Transportation: One-to-one car parking is provided in a secure basement. Four of the apartments are designed as wheelchair accessible.

\subsection{Certified Sustainable Buildings in Turkey}

Tekfen Bomonti Apartments

Building: Tekfen Bomnti apartments

Location: Istanbul, Turkey

Architect: DB Architects

Year: 2012

Project Area: 17,552 m2

Received Certification: $L E E D$

Certification Level: Gold

Assessment Plan: New Building Rating System LEED (NC)

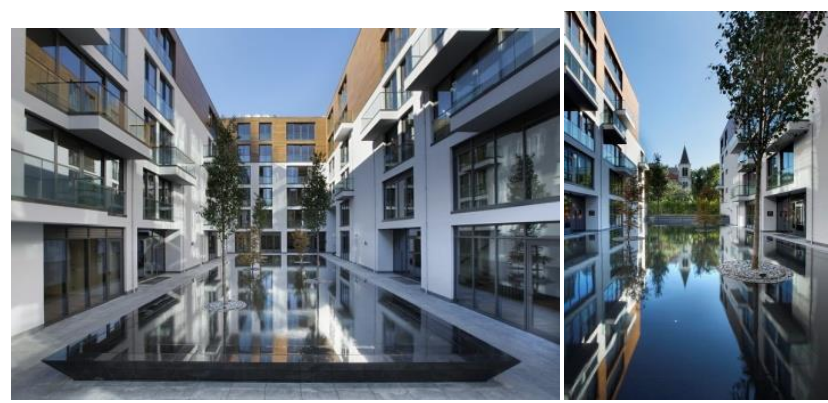

Figure 6 Tekfen Bomonti apartments (Tekfen Bomonti apartmanlari, n.d)

Location: Tekfen Bomonti apartments is a residential building located in Sisli Bomonti. Although Bomonti is one of the urban districts located in the center of the Istanbul, Tekfen Bomonti apartments has preserved the neighbourhood culture.

Architectural Concept: Eco friendly apartment Tekfen Bomonti with 17, 554 m2of indoor space consists of six blocks of apartments and seven stores. Consisting three separate five storey blocks (Figure 4.1), Tekfen Bomonti has inner courtyard with has transitions between residential blocks. This inner courtyard was design for common use for residents (Tekfen Bomonti apartmanları, n.d).

Sustainable Design Features

1. Sun: In Tekfen Bomonti in order to get the maximum use of sunlight there were used wide windows along the façade. Also every residential unit also has individual control of its heating and cooling, allowing the south side to be cooling while the north side may require heating.

2. Water: The drainage system used in Tekfen Bomonti has provided the re use of the storm water. Also inside the building, water conserving fixtures such as low-flow toilets, low-flow showers allow residents to minimize their water use. 
Book of Proceedings

International Conference on Architecture and Spatial Planning

3. Air Quality: Through operable windows in all apartments is provided natural ventilation, cooling and warming. A large percentage of the apartments is ventilated or cooled through these operable windows.

4. Material: In Tekfen Bomonti a large proportion of waste was generated during construction. Also $33 \%$ of buildings materials used in the construction were $28 \%$ recycled content and were obtained from local companies.

5. Transportation: Tekfen Bomonti apartments with walking distance to public transportation, offers a comfortable accessible and living to residential users.

\section{5th Street, Izmir Turkey}

Building: 35th Street

Location: Izmir, Turkey

Architect: Teget Architecture

Year: 2013

Project Area: 130,000 m2

Received Certification: BREEAM

Certification Level: -

Assessment Plan: -

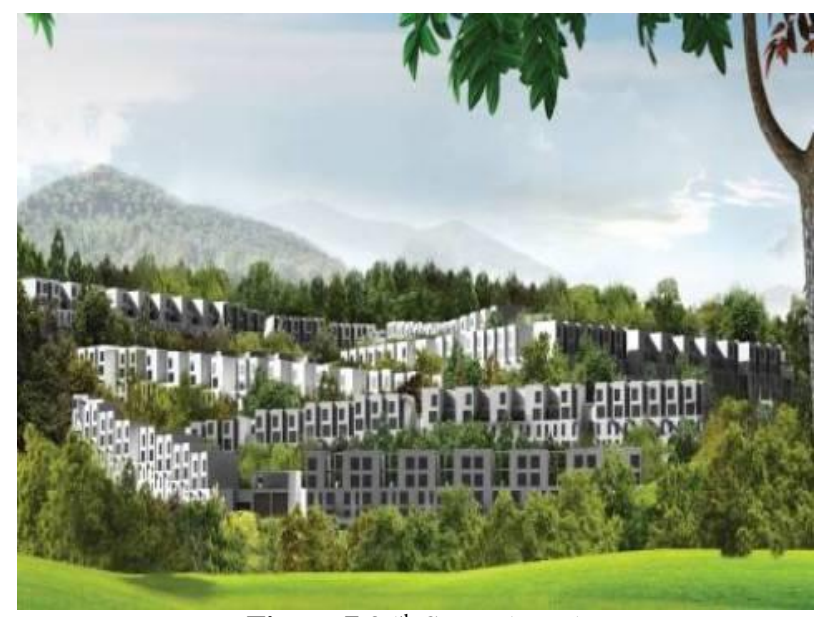

Figure $735^{\text {th }}$ Street $(\ldots \ldots)$

Location: Located in Northern part of İzmir,Ulukent 35th Street Project is formed by the topography of its context. The site is a steep slope which has 60 meters difference in height.

Architectural Concept: The project is a 2 kilometers long curvilinear circulation spine, which extends and grows into private spaces, social amenities as well as infrastructural facilities (Figure 5.5). Spine arrayed along the slope, provides a range of public and private spaces including cafes, bookshops and common spaces and creates a dynamic genealogy. This plan allows unique views overlooking green fields along the corridor, opens up range of different sequences along the spine (35th Street, 2013).

Sustainable Design Features

1. Sun:In 35th Street project was used water heat pumps in order to reduce carbon emissions. Through this heating pump system the use of energy will be reduced. Although $350 \mathrm{~kW}$ of the electricity needs in common facilities and areas on the site is obtained fromsolar panels. In this way by saving $376,00 \mathrm{kWh}$ of electricity, 272 tons per year less carbon emissions are performed. 
2. Water: In 35thStreet project was used the system that collects storm water and re-usedit on the site. 95 thousand square meters of green space and gardens on the site are irrigated through this system. Also with the steel system used in the construction of the houses 30,455 tons of water was saved.

3. Air Quality:

4. Materials: 35th Street is completely built from steel system, which is more resistant to earthquakes as well as $90 \%$ of the steel is converted offers a healthy and environmentally friendly life.

5. Transportation: An archetypical section of the project consists of a continuous underground driveway between parking lots on both sides, a pedestrian street above, and townhouses attached to it. This scheme allows optimized distances between car-parks and the houses, which also helps gaining green areas by embedding parking lots underground.

\section{Conclusion}

In order to prevent unhealthy construction and to increase the number of sustainable or green buildings in terms of the environment, there have been created several sustainable building rating systems i.e. BREEAM, LEED, Green Star, CASBEE and SBTool. These sustainable building rating systems, while maintaining human health and comfort, also tries to decrease the damage of the environment to a lower level.

These voluntary established rating systems are being applied in many different countries from America to Eastern Europe and Japan. Each country has a specific criteria and rating system, depending on the climate and culture. However, these systems cannot be applied in less developed countries or in different climate areas because the criteria of certification systems sometimes do not represent the local situation.

Throughout this research it was aimed to investigate the most widely used rating systems by focusing on BREEAM and LEED rating systems certification categories. Also, this research is aimed to develop general criteria for sustainable condominiums that can be used in all countries, regardless to their economic or regional differences, and these criteria were created by main categories of BREEAM and LEED rating systems. In contrast to the certification system, as these criteria have no need to pre-requisite criteria, are expected to be applicable in any region of the world. And they are;

BREEAM categories;

- $\quad$ Energy: operational energy and carbon dioxide $(\mathrm{CO} 2)$

- Management: management policy, commissioning, site management and procurement

- Health and Wellbeing: indoor and external issues (noise, light, air, quality etc)

- Transport: transport-related $\mathrm{CO} 2$ and location related factors

- Water consumption and efficiency

- Materials: embodied impacts of building materials, including lifecycle impacts like embodied $\mathrm{CO} 2$

- Waste: construction resource efficiency and operational waste management and minimisation

- Pollution: external air and water pollution

- $\quad$ Land Use: type of site and building footprint

- $\quad$ Ecology: ecological value, conservation and enhancement of the site

LEED categories;

- Innovation and Design Location and Linkages

- $\quad$ Sustainable Sites

- Water Efficiency 
Book of Proceedings

International Conference on Architecture and Spatial Planning

\author{
- $\quad$ Energy and Atmosphere \\ - Materials and Resources \\ - $\quad$ Indoor Air Quality \\ - Awareness and Education (http://blueberrypdx.com/leed-certification.htm)
}

Five common criteria certification system were obtained by comparing the two categories. they are;

$\begin{array}{ll}- & \text { Sun } \\ - & \text { Water } \\ \text { - } & \text { Air Quality } \\ \text { - } & \text { Material } \\ & \text { Transportation }\end{array}$

Through these five common criteria is aimed to develop a general criteria for sustainable condominiums that can be used in all countries, regardless to their economic or regional differences. In contrast to the certification system, as these criteria have no need to pre-requisite criteria, are expected to be applicable in any region of the world. According to this certified building around the world and Turkey were exanimated with these five common categories. After the examinationthese result were obtained;

In the building examined form the world were applied criteriaes that directly affects the user comfort such as warming/cooling natural ventilation and transport. And to encourage eco friendly living there were usedlow-flow toilets, washing machines and dishwashers. On the other hand, in the buildings exanimated from turkey the user comfort has been identified as the primer and the most important criteria that were applied.

\title{
References
}

1. 35. Sokak.(n.d). İzmirli 35. Sokak'a tüm Türkiye'den yoğun talep. 23 June 2014, http://www.otuzbesincisokak.com/basin/9nisan_BB.pdf.

2. Bruce, K.B., Cardelli, L., Pierce, B.C.: Comparing Object Encodings. In: Abadi, M., Ito, T. (eds.): Theoretical Aspects of Computer Software. Lecture Notes in Computer Science, Vol. 1281. Springer-Verlag, Berlin Heidelberg New York (1997) 415-438.

3. Best of BREEAM, (n.d), 10 Novmeber 2016, https://www.bre.co.uk/filelibrary/pdf/Brochures/Best_of_BREEAM_2013.pdf)

4. Barry, R.G. \&Chorley, R.J. (1987). Atmosphere, weatherandclimate(5th print). London: Routledge.

5. Breeam, (n.d), 3 Novmeber2014, http://www.breeam.org/filelibrary/BREEAM_Brochure.pdf.

6. Benschneider, B. (b.t). Benjamin Benschneider photography. 22 June 2014, http://www.benschneiderphoto.com/gallery.html?folio=Portfolio\&gallery=Portfolio\#/0

7. BREEAM (Building research establishment environmental assessment methodology). (n.d). 15 September 2014, http://www.breeam.org/. BREEAM sertifikası. (2011). 15 February 2014, http://www.yesilbina.com/BREEAMSertifikasi_a14.html.

8. Brown, G.Z. \&Dekay, M. (2001). Sun, wind\&light-architecturaldesignstrategies. New York: John Wiley\&Sons. 
An Evaluation on Applications of Sustainable Approaches in Condominiums

9. Dahl, D. \& Gurry, D. (n.d). Mosler Lofts, 22 June 2014, http://cba.epropertydata.com/photos/pdf/fs/532806_1.pdf.

10. Dauncey, G. (n.d), Quotes, 19 June 2014, http://www.betterworld.net/heroes/pagesd/dauncey-quotes.htm.

11. Decleris, M. (2000). The law of sustainable development: General principles. Luxembourg: European Commission.

12. Diesendorf, M. (2000). Sustainability: The corporate challenge of the 21th century. Sustainability and sustainable development. Sydney: Allen and Unwin

13. Drexhage, J. \& Murphy, D. (2010). Sustainable development: From Brundtland to Rio 201. New York United Nations Headquarters.

14. Halliday, S. (2008). Sustainable Construction. (1st edition). Oxford: Gaia Research. Leadership in energy \& environmental design. (n.d). 01 June 2014, http://www.usgbc.org/leed.

15. Leed platinum certification, (n.d.) 4 November 2014 ,

16. Regenerative architecture: A pathway beyond sustainability. 4 November 2014, http://blueberrypdx.com/leedcertification.htm. Littman, J.A. (2009).

17. http://scholarworks.umass.edu/cgi/viewcontent. cgi? article $=1389 \&$ context=theses.

18. Mosler Lofts / Mithun. (2011). 22 June 2014, http://www.archdaily.com/123409/moslerloftsmithun/.

19. Mosler Lofts green story. (2008). 22 June 2014, http://mithun.com/knowledge/article/mosler_lofts/ Press cuttings for Vega building identity and signage design. (2013).

20. Mosler Lofts 2720 third ave Seattle, WA 98121. 22 June 2014, http://seecsolutions.com/wp-content/uploads/2010/09/MoslerLofts-Case-Study-PeerReviewed-Agent-Version.pdf S

21. Southern Housing Group: Vega, Kingsway, Hove. (2014). 23 June 2014, http://www.insidehousing.co.uk/southern-housing-group-vegakingswayhove/7003066.article.

22. Tekfen Bomonti apartments. (n.d). 23 Haziran 2014, http://coldwellbanker.com.tr/tr/istanbulsisli/satilik/fiyati-dustu-tekfen-bomontiapartmanlarinda-satilik-10-28561.html\#.U2dQUq1_tsk.

23. Three pillars of sustainability, (n.d). 30 October 2014, http://truist.com/the-three-pillarsofsustainability. 